\title{
Etchings and 还enpoints
}

the collection of

\section{Juton \\ of etflenuiffe, 玵。 照。}

Tame A. 伍hittler

ID. 唡. Cameron

Sir f. Scpumaur lyaden

CYhartes agernon
Antor \%orn

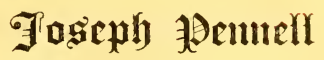

feetix $\mathfrak{D}$ bulfot

聇aul hajoun

and

瓦awíngs

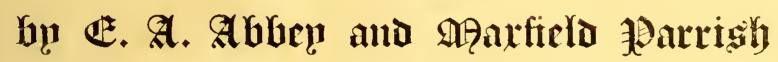

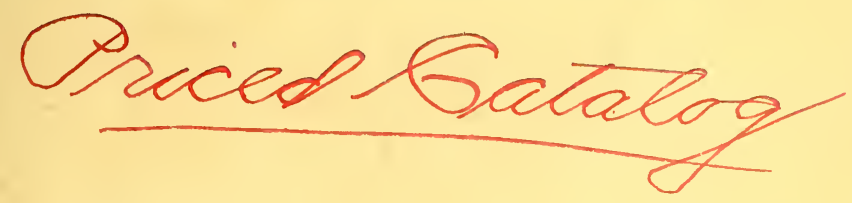

9

The Anderson Art Gallertes

12 Eagt 46 th 5 treet

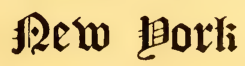

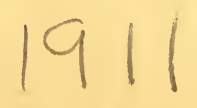


SMITHSONIAN

INSTITUTION

4 CQK. 



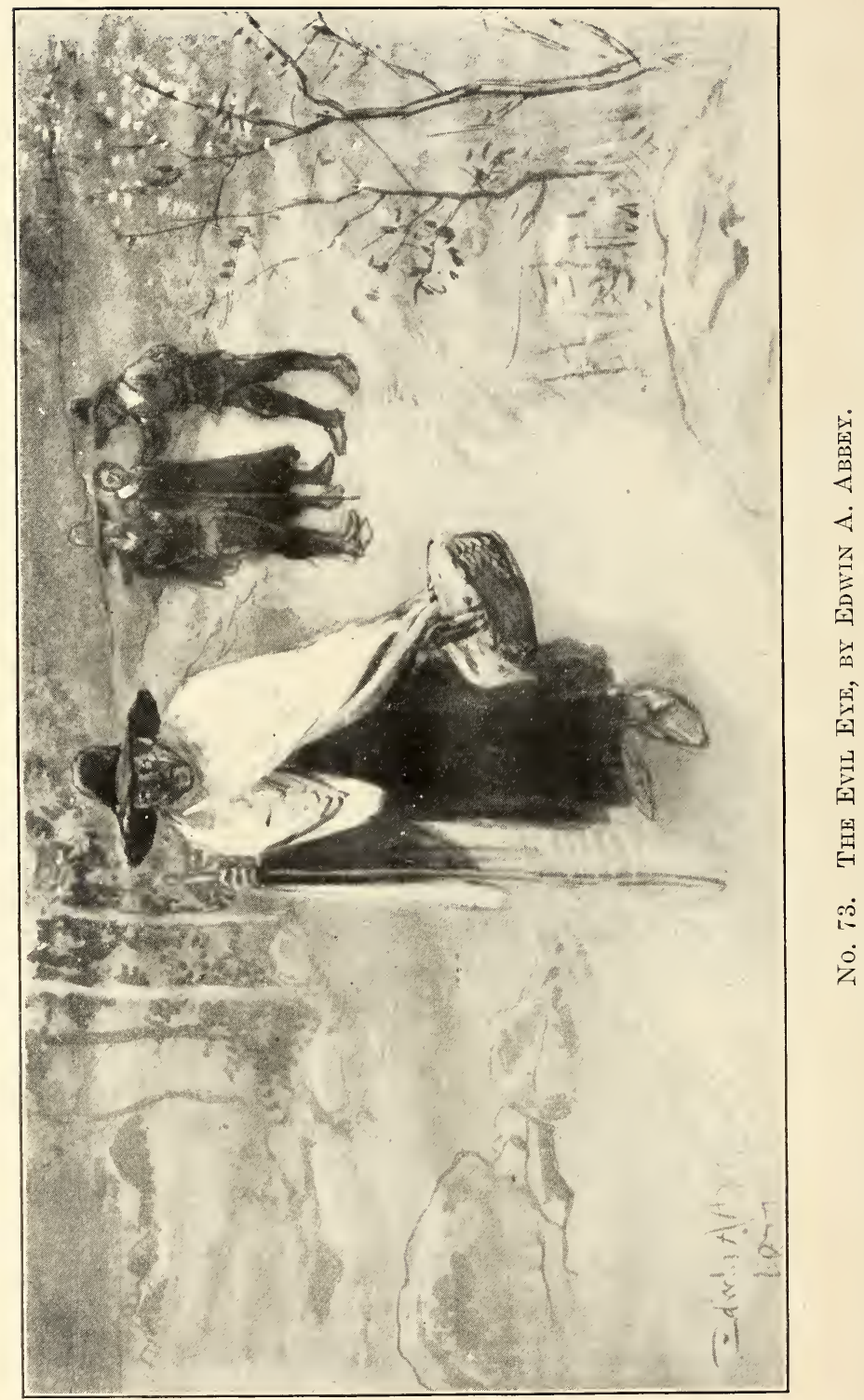




\section{ETCHINGS AND DRYPOINTS}

THE PROPERTY OF

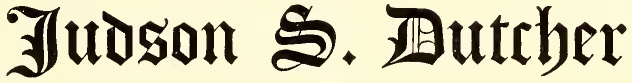

OF ELLENVILLE, N. $Y$.

Whistler's “Price's Candle Works," Two Undescribed First States;

Trial Proof of "The Two Doorways"; Undescribed Trial

Proof of "The Greenwich Pensioner," among Seventy-six

Rare Signed Proofs and other Whistler Items ;

Tile only known Copy of the First State

of Zorn's "OMnibus," "The Waltz"

and "The Cigarețte Girl,"

and other Zorn Prints;

"The Y, Amsterdam" characterized by Cameron as One of only

Two Proofs. the “Five Sisters" “St. Mark's No. 2," ahong

the Cameron Prints; Rajon's "Suzanna Rose," Trial

Proof ; Trial Proof of Haden's "Mytton Hall,"

and First State of "On thie Test"; a Proof

of Merron's "Pont au Change";

Buhot's "Petites Chaumières," “Country Neighbors”; and "Bergeries"; and other Rare Signed Trial Proofs, First States and Fine

Impressions ; a Drawing by Maxfield Parrish,

and Four Drawings in Crayon and

Wasir, by Edwin A. Abbey.

TO BE SOLD

TUESDAY EVENING, FEBRUARY 14, 1911

BEGINNING AT $\mathbf{8 . 1 5}$ O'CLOCK.

On Exhibition from Wednesday, February 8, 9 a.m. to 5.30 P.м.

\section{The Anderson Aurtion Company}

12 EAST $46 \mathrm{TH}$ STREeT

NEW YORK

Telephone, Bryant 271 


\section{Conditions of Sale.}

1. All bids to be per Lot as numbered in the Catalogue.

2. The highest bidder to be the buyer; in all cases of disputed bids the lot shall be re-sold, but the Auctioneer will use his judgment as to the good faith of all claims and his decision shall be final. He also reserves tse right to reject any fractional or nominal bid which in his judgment may delay or injuriously affect the sale.

3. Buyers to give their names and addresses and to make such cash payments on account as may be required, in default of which the lots purchased to be immediately resold.

4. The lots to be taken away at the buyer's expense and risk within twenty-four hours from the conclusion of the sale, and the remainder of the purcl ase money to be absolutely paid on or before delivery, in default of which the Anderson Auction Company will not be responsible if the lot or lots be lost, stolen, damaged, or destroyed, but they will be left at the sole risk of the purchaser, and subject to storage charges.

5. To prevent inaccuracy in delivery, and inconvenience in the settlement of purchases, no lot will be delivered during the sale.

6. All lots will be exposed for public exhibition two or more days before the date of sale, for examination by intending purchasers, and the Anderson Auction Company will not be responsible for the correctness of the description, authenticity, genuineness, or for any defect or fault in or concerning any lot, and make no warranty whatever, but will sell each lot exactly as it is, without recourse. But upon receiving before the date of sale expert opinion in writing that any lot is not as represented, the Anderson Auction Company will use every effort to furnish proof to the contrary, and in default of such proof the lot will be sold subject to the declaration of the aforesaid expert, he being liable to the owner or owners thereof for damage or injury occasioned by such declaration.

7. Terms Cash. Upon failure to comply with the above conditions any sum deposited as part payment shall be forfeited, and all such lots as remain uncleared after twenty-four hours from the conclusion of the sale, will be re-sold by either private or public sale at such time as the Anderson Auction Company shall determine, without further notice, and if any deficiency arises from such re-sale it shall be made good by the defaulter at this sale together with all the expenses incurred thereby. This condition shall be without prejudice to the right of the Anderson Auction Company to enforce the contract with the buyer, without such re-sale.

- The Anderson Auction Company will afford every facility for the employment of carriers and packers by the purchasers, but will not be

responsible for any damage arising from the acts of such carriers and packers.

THE ANDERSON AUCTION COMPANY, 12 East 46Th Street, New York. 


\section{ILLUSTRATIONS}

Abbey (Edwin A.)-The Evil Eye (Frontispiece) No. 73

Abbey (Edwin A.)--The Skeleton in Armor . . 71

Cameron (D. Y.) - The Y, Amsterdam . . . . 19

Cameron (D. Y.) - St. Mark's No. 2 , . . . . . 28

Haden (Sir F. Seymour) -Mytton Hall , . . . 50

Rajon (Paul)-Suzanna Rose . . . . . . . . . 67

Whistler (J. A.) - Price's Candle Works. . . . . 125

Whistler (J. A.)-Greenwich Pensioner . . , . . 97

Whistler (J. A.) - The Doorway . . . . . . . 133

Whistler (J. A.) - Fanny Leyland . , . . . . 119

Zorn (Anders) - The Omnibus . . . . . . . . 154

Zorn (Anders)-Mrs. Kip . . . . . . . . . 161 



\section{NOTE.}

MORE than ten years ago Sir Frederick Wedmore wrote the introduction to the second edition of his catalogue of Whistler Etchings that these prints were so scattered and so many of them were and always must be so very rare that he would have been unable to compile his catalogue without the help of "several diligent collectors" on both sides of the water. Bourcard repeats this statement in 1903, and the compiler of each of the catalogues printed since Wedmore's has had much the same thing to say in regard to the difficulty of forming a collection of the etchings and drypoints of an artist who ranks as the greatest etcher of the Nineteenth Century.

It is therefore an event of more than usual interest when one of these great Whistler Collections comes to be dispersed. That of Mr. Judson S. Dutcher, described in the following catalogue, has long been known as one containing many prints of the greatest rarity. The rarest of Mr. Dutcher's prints will be exhibited with the reproductions from that catalogue, thus forming an intelligent basis for comparison. Among them will be found two undescribed states of Price's Candle Works; a superb impression of the Second State of "The Doorway" among ten out of the twelve composing The Venice Set; the French Set complete, including two brilliant impressions of "The 
Kitchen "; and a trial proof of "The Greenwich Pensioner," with Whistler's annotations.

Among the prints which make the collection notable are the only known copy of the first state of Zorn's "Omnibus," and the equally rare "Cigarette Girl"; the wonderful detail of "The Waltz"; the "Y, Amsterdam," characterized by Cameron as one of only two proofs; his "St. Marks No. 2"; the exquisite delicacy of the work on Rajon's "Suzanna Rose"; a trial proof of Haden's "Mytton Hall "; a proof of Meryon's "Pont au Change," with the imaginative influence of the balloon "Speranza." There are also four drawings in wash and crayon by Edwin $\mathrm{A}$. Abbey, and one in pen-and-ink by Maxfield Parrish, executed with the care and attention to detail for which he is known. 
No. 894

\section{ETCHINGS AND DRYPOINTS}

THE PROPERTY OF

\section{Jud}

OF EILENVILLE, N. Y.

\section{FELIX BUHOT.}

1. LE PUITS DE LA BUTTE AUX CAILlES. Bourcard 41.

Proof signed " F. B."

2. EN PROVINCE: LA MAISON D'ORLEANS A VALOGNES. B. 65 .

Proof on thin Japan paper.

3. FÊTE NATIONALE, BOULEVARD CLICHY. B. $12 \%$.

Third state of four.

4. DÉBARQUEMENT EN ANGLETERRE. B. 130.

Early and very fine impression before the cleaning of the margin of the plate.

* Night effect. The view is of Folkstone Pier, the landing place of the Boulogne boats.

5. DÉBARQUEMENT EN ANGLETERRE. B. 130.

Contre-épreuve on Van Gelder paper toned by the etcher. Proof stamped by Buhot with his red stamp.

* This gives the preceding plate with day effect.

6. LES VOISINS DE CAMPAGNE (COUNTRY NEIGHBOURS). B. 148.

Artist's proof, with the symphonic margin. Signed by Buhot, and with his red stamp.

* One of Buhot's delightfully humorous plates. 
FELIX BUHOT-Continued.

\%. LES PETITES CHAUMIERES. B. 149.

Very fine impression. Proof signed by Buhot and with his red stamp.

8. LES GRANDES CHAUMIERES. B. 150.

Very fine proof, rich with burr.

Monogram drawn in pencil and in Buhot's handwriting: "Be Etat. État avec les barbes. F. B."

9. BERGERIES: SOLEIL COUCHANT. B. 151.

Signed with his monogram drawn in red crayon, and with his red stamp, and also with the following in his handwriting: "Bergeries à Quineville. (État?) le ciel rétouché à la pointe."

* One of Buhot's most famous plates. Only on his very finest proofs did Buhot draw his monogram as here. Printed on a toned Van Gelder paper.

10. LES OIES. B. 166.

Proof stamped with Buhot's red stamp.

11. ZIGZAGS D'UN CURIEUX. B. 172.

Second state of four, with symphonic margins.

\section{DAVID YOUNG CAMERON.}

12. DUNDEE. Wedmore 4.

ONE OF ONLY THREE PROOFS. On 17th century paper.

Signed by Cameron, and on the back in his handwriting, Dundee. 1 of 3 proofs."

* Cameron's early work is almost entirely pure etching, the drypoint rarely used. Nearly all the plates are printed by him self in issues of from 30 to 50 copies, and in as few states as possible. The majority of his plates are very rare.

13. GREENOCK. W. 8 .

TRIAL PROOF before the heavy work in foreground at left, covering the signature, which was rewritten at right without date.

Signed by Cameron. On toned Van Gelder paper.

14. TWEEDSIDE. W. 13.

Proof signed by Cameron, on Van Gelder paper.

15. TAYSIDE. W. 14.

Proof signed by Cameron, on Japan paper.

Very fine impression. 



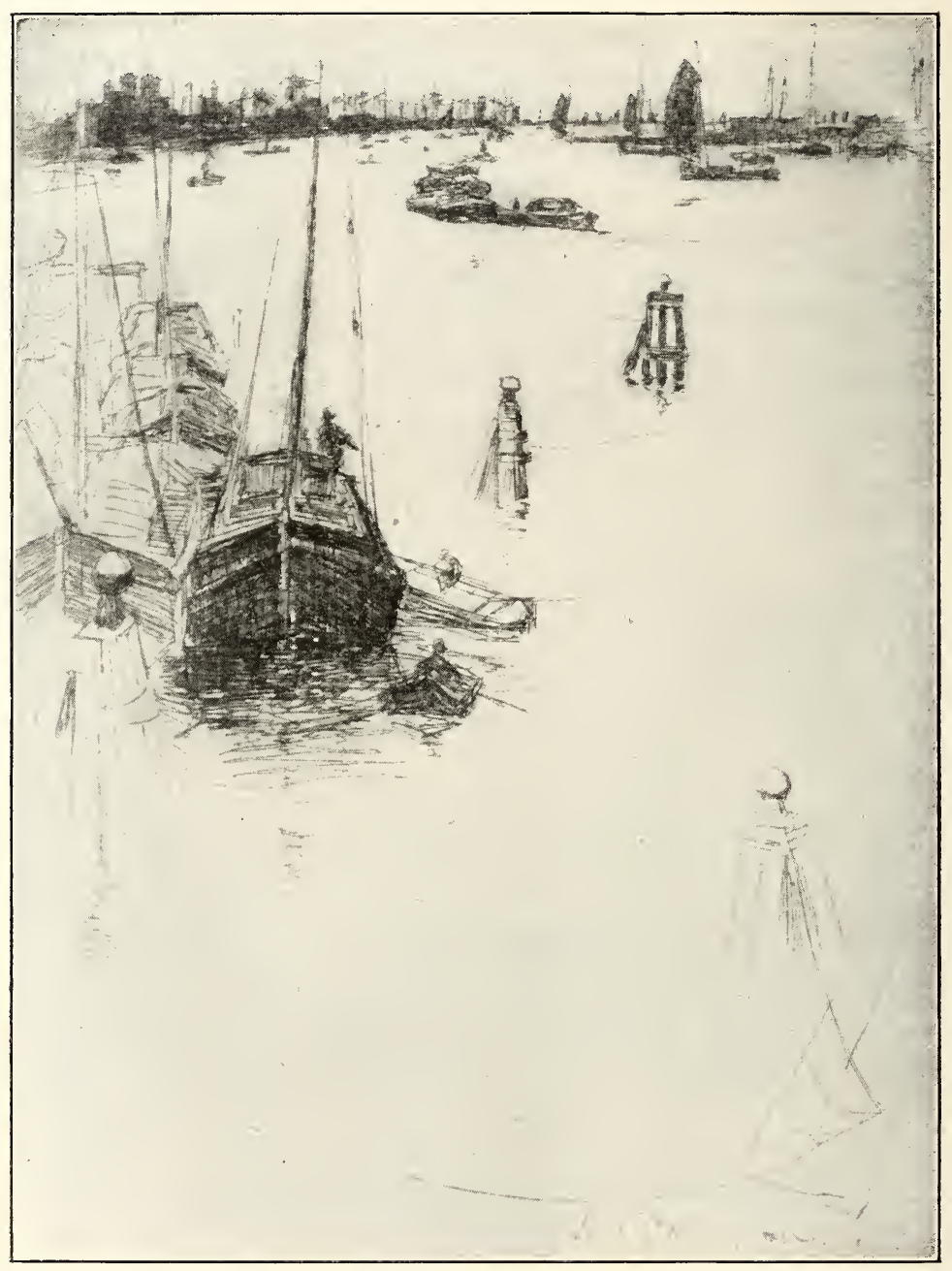

No. 19. The Y, By D. Y. Cameron. 
DAVID YOUNG CAMERON-Continued.

16. ZAANDAM, WINDMILLS. W. 43.

First state.

Proof signed by Cameron, and on the back in his handwriting: "Zaandam, Windmills, only proof 1st state."

17. ZAANDAM, WINDMILIS. W. 43.

Second state.

Proof signed by Cameron, and on the back in his handwriting: "Zaandam Windmills. (Dutch Set.)"

18. THE ROKIN, AMSTERDAM. W. 46.

Proof on old French paper.

Signed by Cameron, and with the title in his hand. writing.

19. THE Y, AMSTERDAM. Unknown to Wedmore. Grolier 48.

Signed proof. Written on the back in the etcher's autograph is: "The $Y$, Amsterdam. Only proof."

* Mr. Cameron in a recent letter to Mr. Dutcher states that there WERE ONLY TwO PROOFs taken, the location of the other: apparently unknown to him,

[See Illustration.]

20. A DUTCH DAMSEL. W. 50.

Proof signed by Cameron on 18th century paper.

Very beautiful impression.

* One of his scarcest plates.

21. VERONICA, A MAID OF ITALY. W. $8 \%$.

Proof signed by Cameron. On old French paper.

Superb impression.

22. THE BRIDGE OF SIGHS AND DOGE'S PALACE, VENICE. W. 78 .

Proof on seventeenth century paper, signed by Cameron.

23. VENICE FROM THE LIDO. W. $8 \%$.

Proof signed by Cameron and with the title in his hand writing.

Very fine impression.

* A rare plate. 
DAVID YOUNG CAMERON-Continued.

24. LA COUR DES BONS-ENFANTS (ROUEN). W. 110.

Proof signed by Cameron, on China paper.

* Magnificent impression of one of his masterpieces. VERY RARE.

25. HENRY THE EIGHTH'S CHAPEL. W. 126.

Proof signed by Cameron.

26.'ST. PAUL'S. W. $12 \%$.

Undescribed state, before the burr was removed.

Proof signed by Cameron, and in his handwriting: " St. Paul's from the river, trial proof."

27. ROSLYYN. W. 130.

Proof on old French paper, signed by Cameron.

28. ST. MARK'S, No. 2. W. 132.

Very beautiful trial proof before the shadows were deepened and extended.

Signed by Cameron and with the following in his autograph: "Trial proof, San Marco, Venice." On Japan paper.

[See Illustration.]

29. CASA D'ORO, VENICE. W. 138.

Trial proof before certain reflections in the water and before the highest window at the right was shaded. On thin Japan paper.

Proof signed by Cameron. VERY RARE.

30. CHARTRES. W. 145.

Proof signed by Cameron, and with the title in his handwriting. On thin Japan paper.

31. ST. MERRI, PARIS. Grolier Catalogue No. 196.

Proof signed by Cameron, and with the title in his handwriting. On Japan paper.

32. BERWICK ON TWEED. Gr. $19 \%$.

Proof signed by Cameron, on thin Japan paper.

33. ROBIN HOOD'S BAY. Gr. 199.

Proof signed by Cameron, and with the title in his handwriting. On old French paper. Superb impression.

34. EVENING ON THE GARRY. Gr. 213.

Proof signed by Cameron, and with the tltle in his hand writing. On thin Japan paper. 


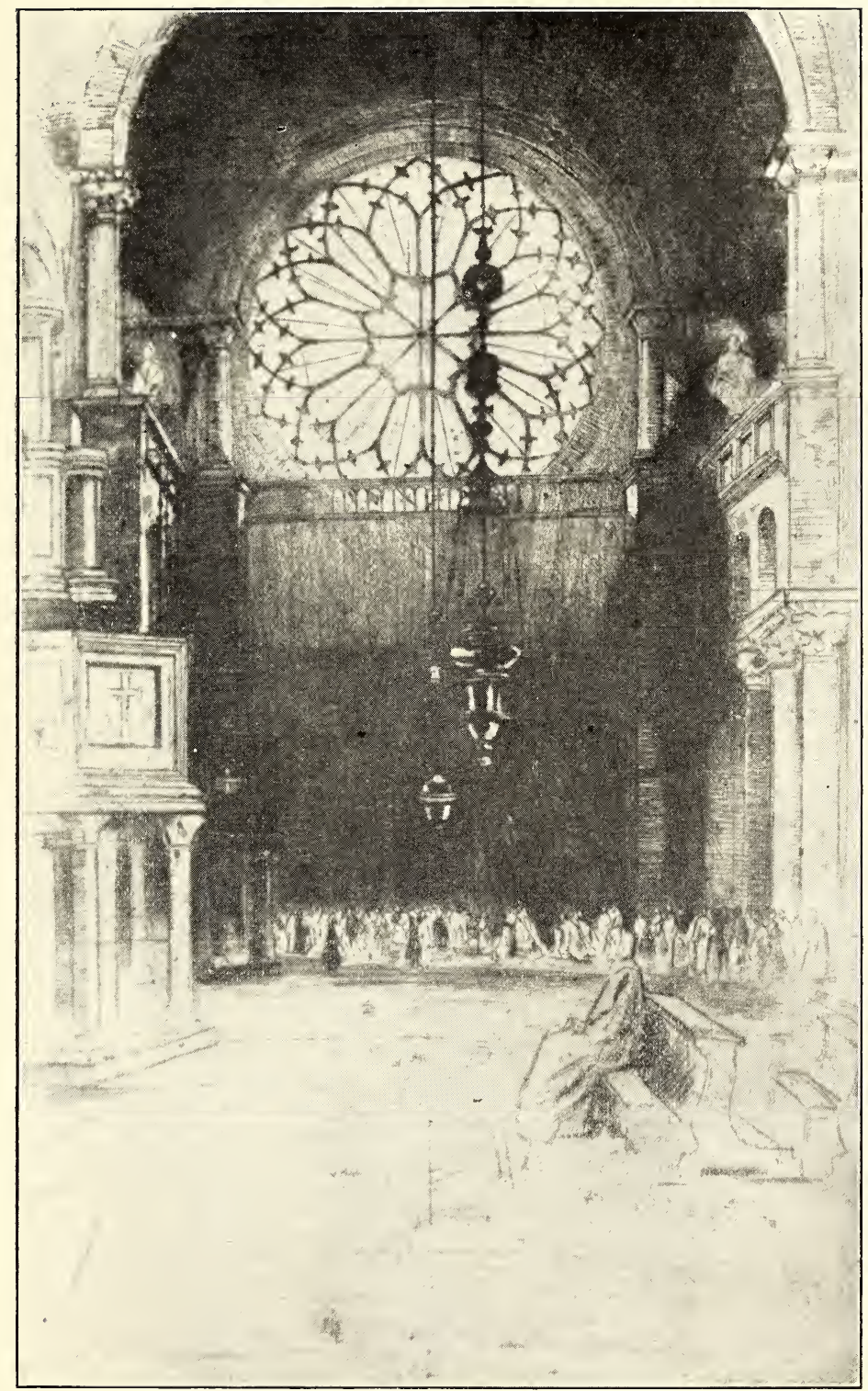

No. 28. St. Mark's No. 2, by D. Y. Cameron. 

DAVID YOUNG CAMERON-Continued.

35. MAR'S WORK, STIRLING. Gr. 214.

Proof on thin Japan paper, signed by Cameron.

36. THE FIVE SISTERS, YORK MINSTER. Gr. 215.

Proof on thin Japan paper, signed by Cameron. A superb impression.

ONE OF CAMERON'S MASTERPIECES AND EXTREMELY RARE.

3\%. AFTERGLOW ON THE FINDHORN. Gr. 216.

Proof on thin Japan paper, signed by Cameron. Very fine impression.

38. MY LADY OF LUXOR.

Proof on thin Japan paper, signed by Cameron.

39. SKETCH ON THE TAY. Proof on old French paper, signed by Cameron.

40. OLD WHITBY BRIDGE.

Proof on 18th century paper, signed by Cameron.

A very beautiful impression.

\section{TIMOTHY COLE.}

41. PORTRAIT OF TIMOTHY COLE. After Wyatt Eaton.

Wood engraving by himself. Proof from the original block on China paper, signed by the engraver.

42. BURIAL OF THE VIRGIN. After Duccio of Siena.

Wood engraving. Proof from the original block, on China paper, signed by the engraver, and with autograph inscription, "To my dear friend Wyatt Eaton wlth compliments of T. Cole."

43. ST. AGNES. After Del Sarto.

Wood engraving. Proof from the original block, on China paper, signed by the engraver.

44. THE THREE AGES OF MAN. After Lorenzo Lotto.

Wood engraving. Proof from the original block, on China paper, signed by the engraver.

45. THE CONCERT. After Giorgione.

Wood engraving. Proof on China paper, from the original block, signed by the engraver. 


\section{ALBRECHT DURER.}

46. ALBERT OF MAINZ (KNOWN also as The LitTIE Cardinal). B 102.

Copper engraving. Early and good impression showing clearly the windows reflected in the eyes, but trimmed close and slightly skinned on the back in one place. From the William Sharp and another collection.

47. JOACHIM AND ANNA EMBRACING AT THE GOLDEN GATE. B. 79.

Wood engraving from the Life of the Virgin.

Very early impression on paper, with the watermark Hausmann 28. (Dürer's First Period.) Isatin text on the back.

\section{MARIANO FORTUNY.}

48. IDYLLE. Beraldi 4.

Proof before letters on China paper.

A very beautiful impression.

49. GARDE DE LA KASBAH A TETUAN. B. 5.

Proof before letters on China paper.

Beautiful impression.

\section{SIR FRANCIS SEYMOUR HADEN.}

50. MYTTON HALL. D. 13.

Trial ProOF " $A$." SUPERB IMPRESSION on Dutch paper.

Presentation Proof signed by Sir F. Seymour HADEN, and with the following inscription in his autograph: "Mytton Hall, Lancashire. Seymour Haden à Mons. Fantin."

[See Illustration.]

51. FULHAM. D. 18.

Trial Proof (b). Very beautiful impression on thick Dutch paper.

52. ON THE TEST. D. 19.

First state. Proof on China paper.

* This plate ranks with the Shere Mill Pond, A Water Meadow, and A Sunset in Ireland, as Haden's most beautiful poetic etchings. 


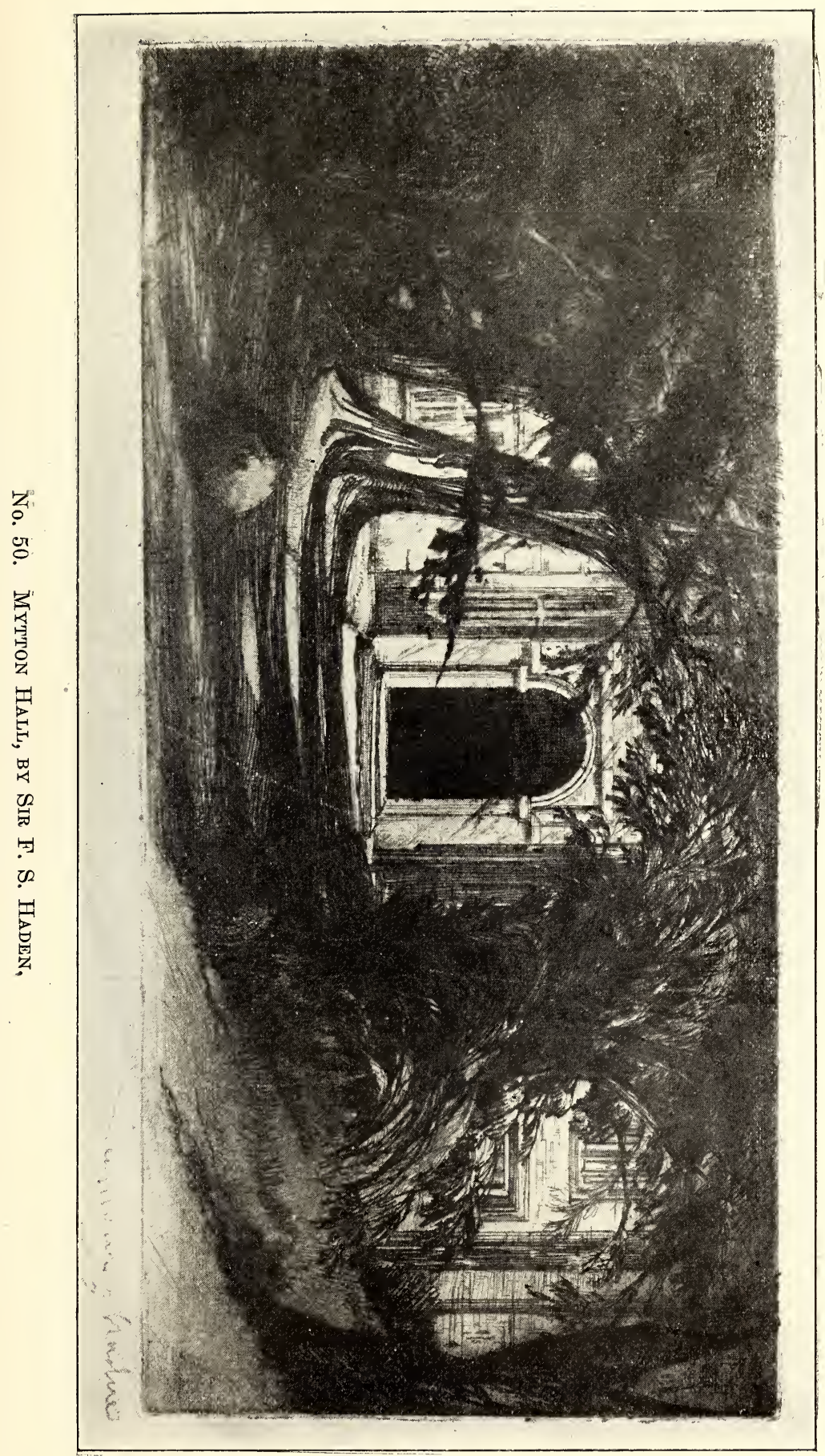



SIR FRANCIS SEYMOUR HADEN-Continued.

53. EARLY MORNING, RICHMOND. D. 21.

Second state, with the inscription: "The lark at heaven's gate sings." On Dutch paper. Very beautiful impression.

* Plate destroyed.

54. KIDWELLY TOWN. D. 22.

First state. On Dutch paper. Very beautiful impression.

Proof signed by Haden, and from HIS OwN COLLECTION with his stamp on the back.

* Plate destroyed.

55. AMSTELODAMUM. D. $3 \%$.

Proof signed " $S$. $H$.", from the Haden collection, with stamp, and in the etcher's handwriting: "D. 37, printed in text-very early-undescribed."

* Plate destroyed.

56. ERITH MARSHES. D. 102.

First state before the clearing of the left half of the sky. Very fine impression.

Proof signed by Haden.

* Plate destroyed.

57. THE MOAT HOUSE. D. 103.

First state.

Proof signed by Haden, FRoM HIS COLLECTION WITH STAMP, and in his handwriting: "2Jrd July, 1876."

58. BREAKING UP OF THE AGAMEMNON. D. 128.

Second state.

Proof signed by Haden, and FROM HIS COLLECTION with stamp.

59. THE KEEP. D. 151.

First state.

Proof signed by Haden, FROM HIS COLLECTION with stamp and in his hand writing: "D. 151. 1st state."

60. WAREHAM BRIDGE. D. 159.

Fine early impression before the horses were completely shaded, and before the hills in the background and the grasses in the right foreground were removed.

Proof signed by Haden. 


\section{CHARLES MERYON.}

61. LE STRYGE. (THE DEVIL OF NOTRE DAME.) Wedmore, \%. Delteil, 23.

Very fine impression before the title with the initials on the chimney and the first address of Delatre, Rue de la Bucheri, 6 (the second address is Rue S. Jacques, 265).

62. LE PONT AU CHANGE. W. 18. D. 34.

VERY BEAUTIFUL PROOF on old paper with only one balloon in the sky, before the hearse on the bridge was altered to a covered carriage, and with the name and date of Meryon.

VERY RARE IN THIS STATE.

63. LA MORGUE. W. 20. D. 36.

Very rich proof on old paper, with the scratched name, address and date of Meryon, bnt before the inscription on the houses or the monogram.

\section{JOSEPH PENNEL.L.}

64. VILLIERS STREET, STRAND.

Signed proof. Very fine early impression, with "Goulding imp.," written in Pennell's hand.

65. LANDING STAIRS, LEGHORN.

Signed proof.

66. AMIENS.

Signed proof.

\section{PAUL, RAJON.}

67. SUZANNA ROSE. After Sandys. Beraldi 148.

VERY BEAUTIFUL TRIAL PROOF before the removal of the needle marks on the bottom margin. On thin Whatman paper.

* One of the masterpieces of etching of the nineteenth century. Beraldi writes of it: "One of the marvels of the century. It is the type of the aged woman of our century; as the Mdme. Letine of Aug. Saint-Aubin is the type of the aged woman of the eighteenth century." Extremely rare.

[See Illustration.] 


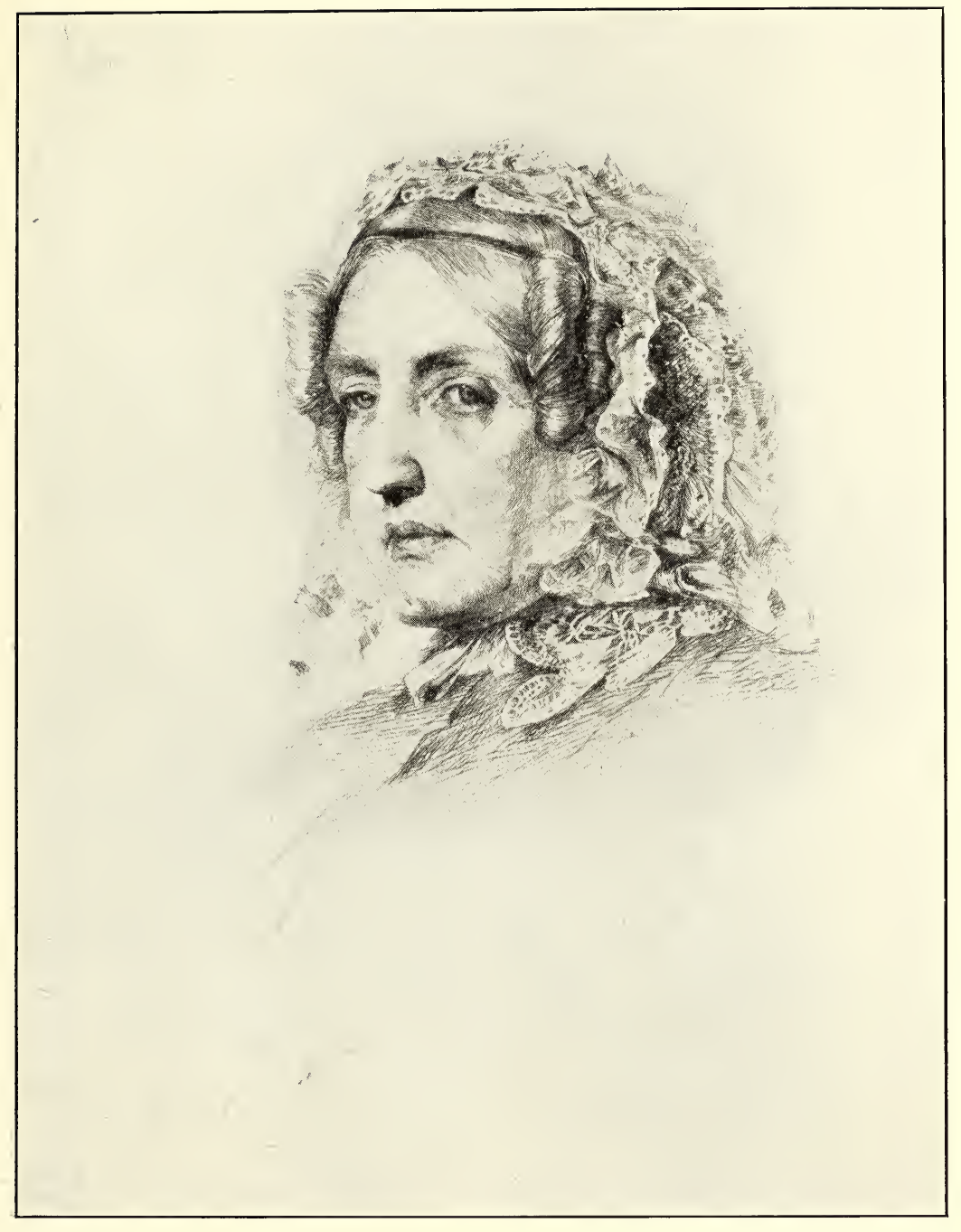

No. 67. Suzanna Rose, by Paul Rajon. 



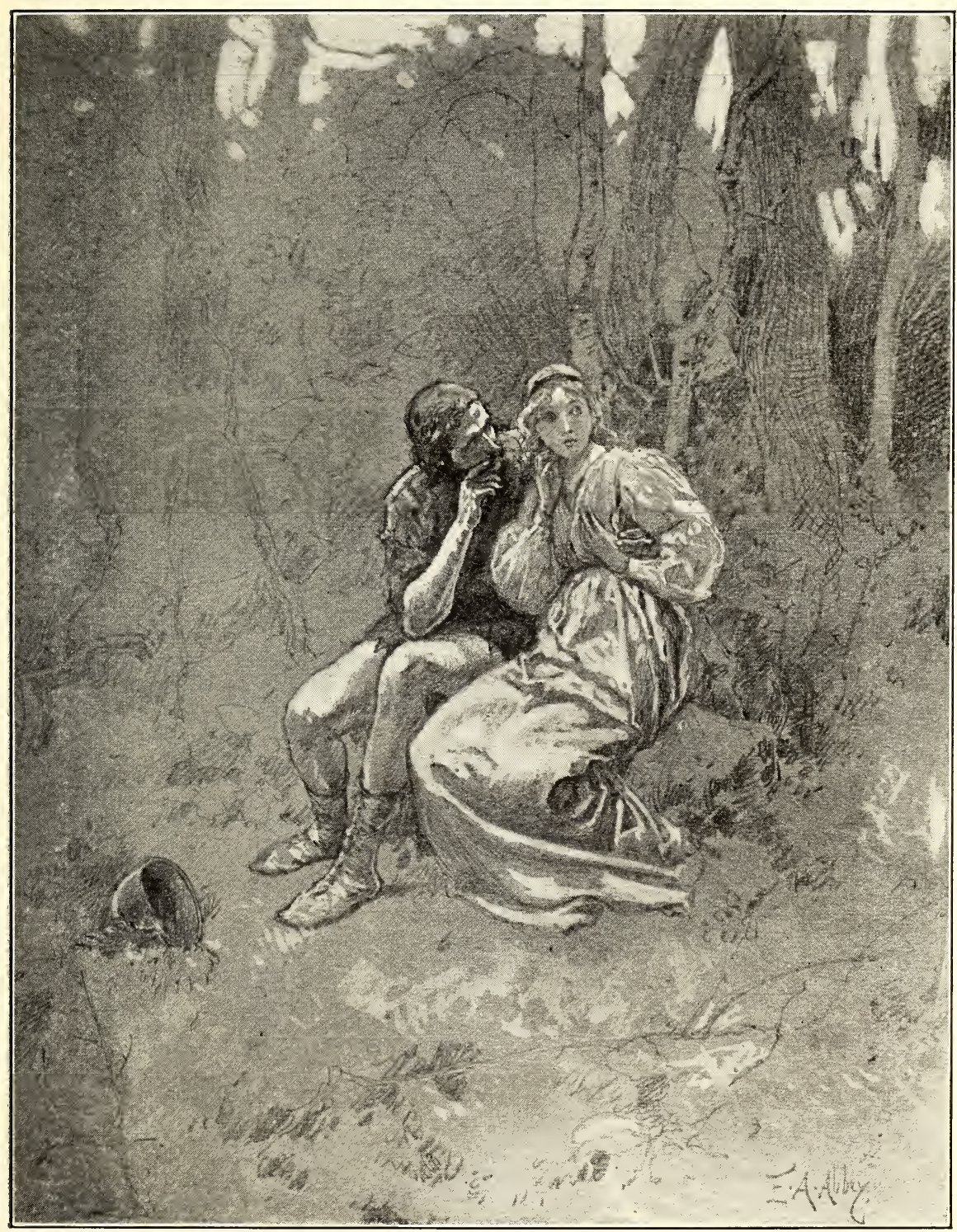

No. 71. The Skeleton in Armor, by Edwin A. Abbey. 



\section{REMBRANDT.}

68. CLEMENT DE JONGHE. Bartsch 272.

Sixth state. On India paper.

69. JAN I.UTMA. Bartsch $2 \% 6$.

Very fine impression on India paper of the finished plate with the signature of Rembrandt. Rare.

\section{HERMAN A. WEBSTER.}

70. NÔTRE DAME ET LE QUAI AUX FLEURS, PARIS.

Signed proof on eighteenth century paper.

ETCHINGS AND DRY POINTS.

\section{ORIGINAL DRAWINGS.}

\section{EDWIN A. ABBEY.}

71. THE SKELETON IN ARMOR.

"I wooed the blue-eyed maid, Yielding, yet half afraid."

Crayon drawing touched with Chinese white on toned paper. Signed E. A. Abbey. 14 x 11 in. Framed.

[See Illustration.]

72. THE CONSTANT MAIDS OF OCKLEY.

Gouache drawing. Signed E. A. Abbey. $14 \times 11 \frac{1}{2}$ in. Framed.

74. THE EVIL EYE. (New England.)

Study in body color. Signed Edwin A. Abbey, 187\%. $21 \times 38$ in. Framed.

[See Frontispiece.]

74. BANISHED FROM MASSACHUSETTS.

Painting in body-color over pen-and-ink. Very finely and carefully finished. Signed E. A. Abbey. $20 \times 26 \frac{1}{2}$ in. Gilt frame.

* The subject of the drawing is the banishment of the Quakers from Massachusetts in 1660 . Whittier wrote a poem on the subject of the drawing in 1884 . 


\section{MAXFIELD PARRISH.}

\section{LITTLE BOY BLUE.}

Pen-and-ink drawing, exquisitely finished. Signed M. P. $12 \times 10$ in. Framed.

\section{ETCHINGS AND DRY POINTS.}

\section{JAMES ABBOTT MCNEILL WHISTLER.}

76. LITTLE ARTHUR. Grolier 9. Mansfield \%. Wedmore 13.

Fifth state. Early impression on yellow China paper. One of the "French set."

* A portrait of Whistler's nephew, the son of Sir Francis Seymour Hayden. The French set, comprising twelve plates and a title-page, was issued in Paris, November, 1858, under the description of "Douze Eaux Fortes d'après Nature." Only a very few were issued and the earliest impressions are usually on yellow China paper. The complete set is in this collection (including a duplicate of "The Kitchen ").

77. ANNIE. Gr. 10. M. 8. W. 15.

Fourth of five states. Very fine early impression on yellow China paper. One of the "French set."

* A portrait of the daughter of Sir F. Seymour Haden. From the Macgeorge and "J. C." (Cox?) collections, with stamp.

78. ANNIE. Gr. 10. M. 8. W. 15.

Fourth of five states. Early impression on yellow China paper.

79. LA MÈRE GERARD. Gr. 11. M. 13. W. 9.

Fourth state. Early impression on yellow China paper. One of the "French set."

An old woman who sold violets at the gate of the Luxembourg.

80. FUMETTE. Gr. 13. M. 15. W. 18.

Fourth state. Early impression on yellow China paper. One of the "French Set."

81. LA RETAMEUSE. Gr. 14. M. 11. W. 5.

Second state. Early impression on yellow China paper. One of the "French Set." 
WHISTLER-Continued.

82. EN PLEIN SOLEIL. Gr. 15. M. 12. W. 6.

Second state. Early impression on yellow China paper. One of the "French Set.",

83. EN PLEIN SOLEIL. Gr. 15. M. 12. W. 6.

Second state. On white China paper. A very fine early impression. With stamps of the Macgeorge and "J. C."' (Cox?) collections.

84. LIVERDUN. Gr. 16. M. 16 . W. 4.

Second state. Early impression on yellow China paper. One of the "French Set."

85. THE UNSAFE TENEMENT. Gr. 1\%. M. 1\%. IV. \%.

Third of four states. Early impression on yellow China paper.

*A very fine impression. In some of the issues of the set this plate is called "The Old Farm," but Whistler himself wrote the better-known title on a copy in the Avery collection. One of the "French Set."

86. STREET AT SAVERNE. Gr. 19. M. 19. W. 11.

Fourth of five states. Fine and early impression on China paper. One of the "French Set."

87. LA VIEILLE AUX LOQUES. Gr. 21. M. 21. W. 14. Second state. Very fine early impression before the removal of Delatre's name and address. On yellow China paper. One of the "French Set."

88. LA MARCHANDE DE MOUTARDE. Gr. 22. M. 22. W. 16.

Third of five states. Very beautiful early impression on yellow China paper. One of the "French Set."

89. THE RAG GATHERERS (QUARTIER MOUFFETARD). Gr. 23. M. 23. W. $1 \%$.

Fifth state with the date 1858, on China paper.

90. THE KITCHEN. Gr. 24. Second state. M. 24. W.

19 (first state). Brilliant impression in brown ink on white China paper.

* Proof signed by Whistler with his pencilled the "French Set." 
WHISTLER-Continued.

91. THE KITCHEN. Gr. 24. Second state. M. 24. W. 19 (first state). Very beautiful early impression on yellow China paper.

92. TITLE-PAGE TO THE FRENCH SET (DELANNOY SKETCHING). Gr. 25. M. 25. W. 20.

Oniy state. Fine impression on yellow China paper.

* Delannoy was Whistler's companion in some of his earlier wanderings through Europe, and he is shown in the plate with the broad-brim hat that is associated with the earlier portraits of Whistler himself.

This plate completes the "French Set."

93. BIBI VALENTIN. Gr. 50. W. 28. M. 50.

Second state. On thin Japan paper.

* Proof printed by Whistler and signed with his pencilled ब्राज imp. With stamp of the Macgeorge collection.

94. SEYMOUR, SEATED. Gr. 29. M. 6. W. 22.

Undescribed state between the first and second. The two vertical lines at the left extend to within an inch of the top of the plate and are crossed by a third line. In the second state they are burnished down to two inches from the top.

A beautiful impression on China paper showing the extremely delicate dry-point lines in the upper right and left corners and on the left knee. A portrait of Seymour Haden, junr.

95. ANNIE, SEATED. Gr. 30. M. 29. W. 24.

Second state, on China paper.

* The daughter of Sir Francis Seymour Haden, also shown standing in Nos. 77 and 78.

96. THE MUSIC ROOM. Gr. 33. M. 31. W. 26.

First State. An impression of the highest quality on old soft eighteenth century paper. Proof signed by Whistler with the pencilled

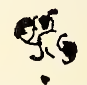

* An interior of a room by lamp-light showing Sir Francis Seymour Haden seated reading a newspaper, Lady Haden, and Mr. Traer, the assistant of Sir F. S. Haden. 



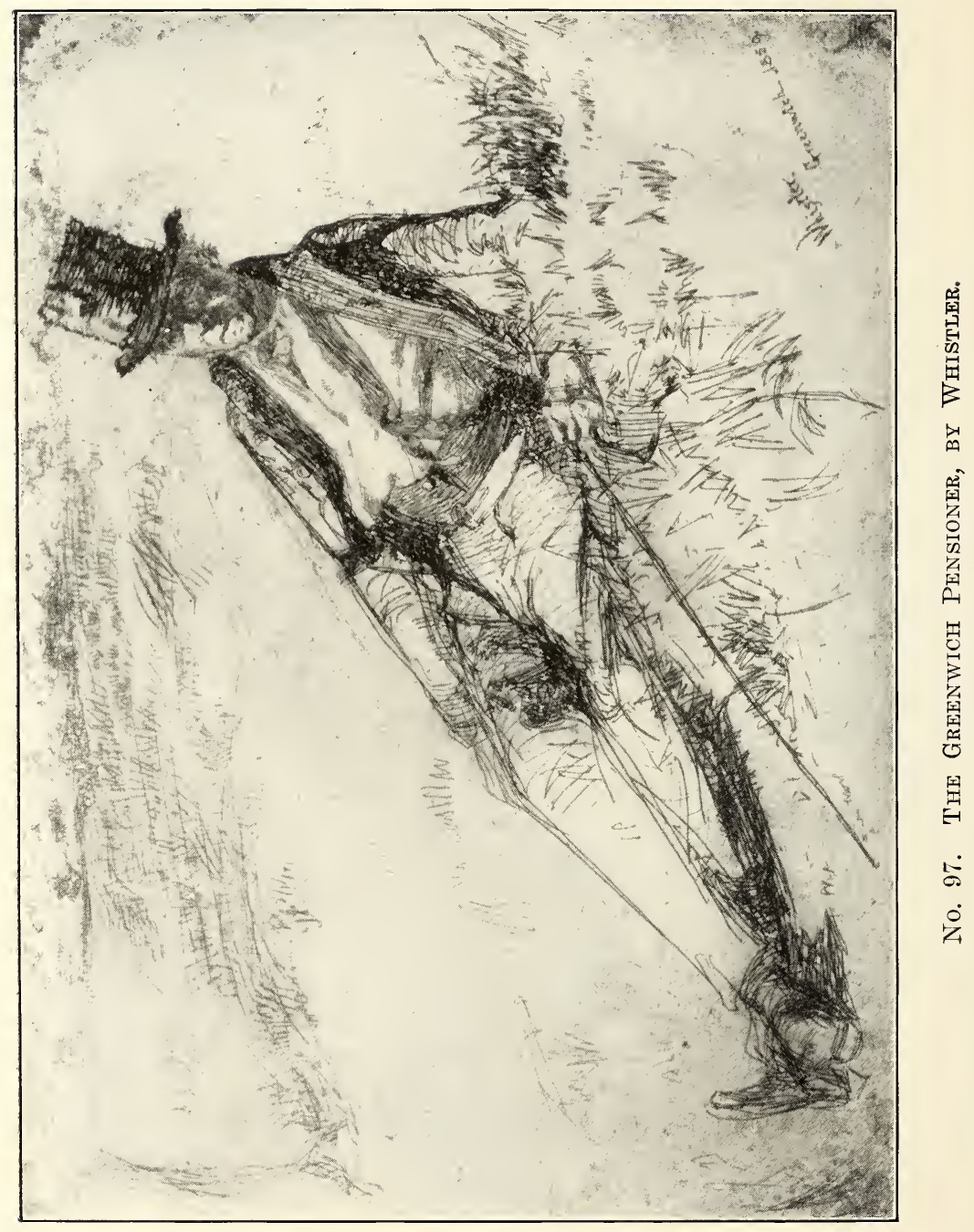


WHISTLER-Continued.

97. GREENWICH PENSIONER. Gr. 34. M. 33. W. 32.

Undescribed Trial Proof. Before the delicate horizontal dry-point lines across the top of the plate and the heavy work on the right arm near the shoulder; also, before the removal of various lines at the left of the figure, especially the double outline of the right arm. There were other changes throughout the plate, which seems to have been freely burnished down later.

Proof signed by Whistler with his pencilled and also with the title "Greenwich Pensioner" written by him. The double signature (in pencil) on this print is a very unusual feature.

[See Illustration.]

98. NURSEMAID AND CHILD. Gr. 3\%. M. 36 . W. 34. The figure of the woman has the nose " rétroussé." According to Mr. Frederick Keppel this is the " rare first state," according to other authorities the "second." A very fine impression on Dutch paper.

99. THAMES WAREHOUSES. Gr. 38. M. 3\%. W. 35.

Second state. Very fine impression showing the outline of the man standing beyond the second barge in the foreground. The heavy dry-point lines rich with burr. On China paper. One of the "Thames Set." View from the Thames Tunnel Pier.

* The plates for the "Thames Set" were executed at intervals several years before they were collected and issued as a series in 1871 . The earliest impressions and states were printed by Whistler himself and are exceedingly rare, although only a very limited number were printed of the later states. All were views on the Thames with one exception, the etching of Becquet, "The Fiddler."

100. EAGLE WHARF. (TYZAC, WHITELEY \& CO.) Gr. 41. M. 40. W. 39.

Only state. Very fine impression on old paper. One of the "Thames Set." 
WHISTLER-Continued.

101. BLACK-LION WHARF. Gr. 42. M. 41 . W. 40.

Third state. Very finely printed impression on Dutch paper.

* One of Whistler's most famous plates, etched in 1859 , and quoted many times as an example of his finished and picturesque work. The third or finished state of this plate is much more effective than the earlier states. One of the "Thames Set."

102. THE LIMEBURNER. Gr. 46 . M. $45 . \quad$ W. 44.

First state with only horizontal lines on the wall at the right between the standing figure and the longer ladders, and before the burnishing out of the slipped stroke extending from near the top of the ladders nearly across the wall. On China paper.

In a later state one of the "Thames Set."

103. THE LIMEBURNER. Gr. 46 . M. $45 . \quad$ W. 44.

Second state. With delicate vertical lines added on the wall, and the slipped stroke burnished out. On thin Japan paper.

In this state one of the "Thames Set."

104. BECQUET (THE FIDDLER). Gr. 52. M. 52. W. 48. Fourth state. Fine impression on thin Japan paper. One of the "Thames Set."

Said to be on a plate first etched by a West Point classmate. Muskets not burnished out may be seen in the lower right corner.

105. DROUET. Gr. 55 . M. 55. W. 53.

Later but fine impression of the finished plate on thin Japan paper.

106. WAPPING (OR ROTHERHITHE). Gr. 66 . M. 66. W. 60 .

Third state. Fine impression on Dutch paper.

One of the "Thames Set."

10\%. THE PENNY BOAT. Gr. 67. M. $6 \%$ W. 59.

First state. A touched proof, the shading (seen in the second state) drawn with a pencil. Printed on 1\%th century paper.

* From the Theobald Collection, but not stamped. 
WHISTLER-Continued.

108. THE FORGE. Gr. 68. M. 68 . W. 63.

Fourth state, with the small blank space to the right of the smith's head.

* A. dry-point executed in Brittany in 1861, and said to have been printed by Whistler himself. One of the "Thames set."

109. VAUXHALL BRIDGE. Gr. 70. M. 70. W. 66.

Second state. On thin Japan paper. Very fine impression.

* Proof printed and signed by Whistler, with his pencilled<smiles>C1=[As][As]1</smiles>

110. MILLBANK. Gr. 71. M. 71. W. 67.

Fifth state. An early impression before the delicate lines in the sky were worn away.

One of the "Thames Set": Looking down the River from Millbank.

111. LITTLE W APPING. Gr. 75. M. 72. W. 71.

Second state. Very fine impression on thin Japan paper.

* Proof printed and signed by Whistler with his pencilled पivis $i m p$.

112. THE LIT'TLE POOL. Gr. 74. M. 73. W. 72.

Eighth state. With the etched signature "Whistler, 1861." One of the "Thames set." Whistler himself and Sergeant Thomas are the figures.

113. EARLY MORNING, BATTERSEA (CAdogan Pier). Gr. 75. M. 75 . W. 79.

Only state. Fine impression of this delicate drypoint, on China paper.

One of the "Thames Set."

114. OLD HUNGERFORD BRIDGE. Gr. 76. M. 76. W. 80.

Third state. Very fine impression on thin Japan paper.

One of the "Thames Set."

115. THE PUNT. Gr. 85 . M. 86. W. 68.

Third of four states, before "Pl. $r$ " in the right upper corner.

Proof on India paper. 
WHISTLER-Continued.

116. SKETCHING. (THE THAMES.) Gr. 86. M. $8 \%$. W. 69 .

Undescribed state, between the first and second. Before the plate was burnished at the top and bottom, removing certain lines from the sky and part of the grasses at bottom, as well as a part of the leg of the artist's stool.

India proof.

11\%. THE MODEL RESTING. Gr. 100. W. 8\%. M. 118. Fourth of six states.

* Proof printed by Whistler and signed with his pencilled gif $i m p$.

-

From the Macgeorge and "J. C." (Cox?) collections.

118. CHELSEA WHARF. Gr. 89. M. 89 . W. 81.

Second state. Fine impression of a very delicate etching, printed by Whistler himself. From the Theobald collection, but not stamped.

Proof signed by Whistler with his name "Whistler" and the title of the plate in his autograph.

* The earliest plate to bear the etched butterfly. In this the butterfly is in "its earliest form-an outline. Bourcard describes this plate as adorable."

119. FANNY LEYLAND. Gr. 108. M. 10\%. W. 94.

Fourth of six states. A superb impression.

* Proof printed and signed by Whistler, with his pencilled

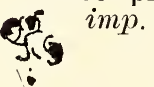

[See Illustration.]

120. ELINOR LEYLAND. Gr. 109. M. 108. W. 95.

Fourth state of seven. Very rich impression on Dutch paper from the Macgeorge Collection, with stamp.

* Proof printed and signed by Whistler, with his pencilled imp. and also with "Babs," apparently in his handwriting, at the bottom.

121. FLORENCE LEYLAND. Gr. 110. M. 109. W. 96. Sixth state of nine. A rare plate on old 18th century paper. 


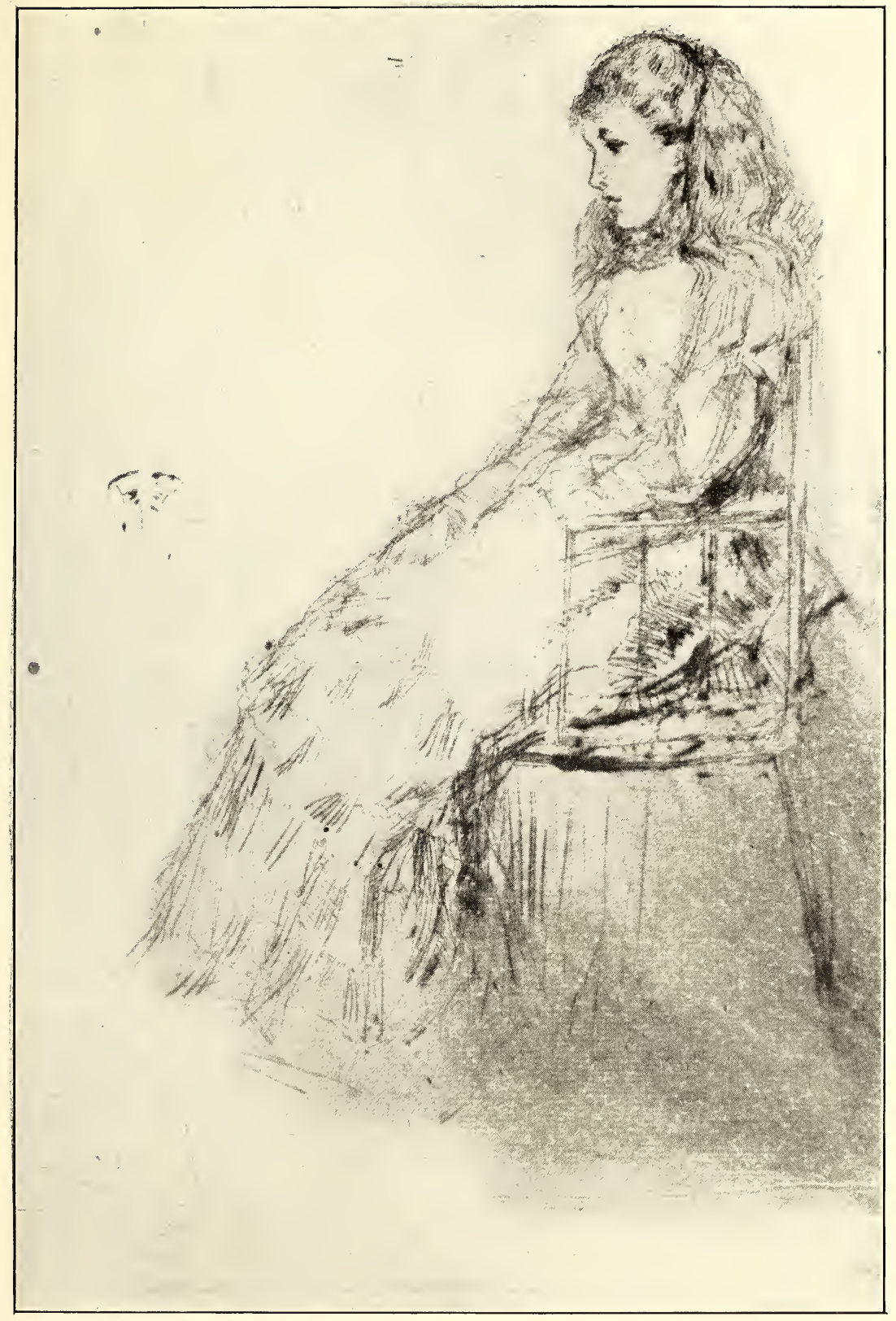

No. 119. Fanny Leyland, by Whistler. 



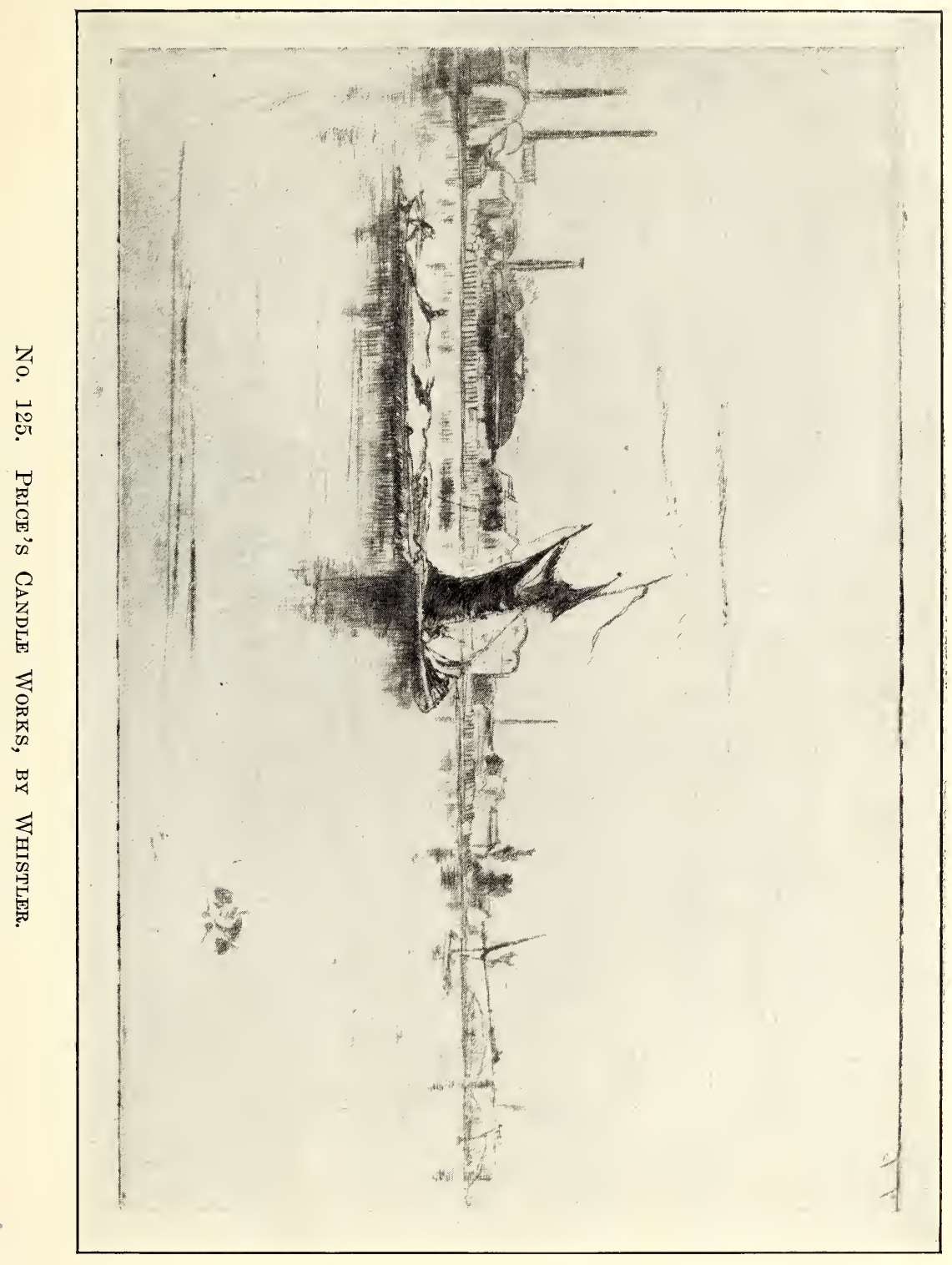



WHISTLER-Continued.

122. TATTING. Gr. 112. M. 111. W. 98.

Only state. Early impression on thin Japan paper.

A portrait of one of the Misses Leyland.

123. THE DAM WOOD. Gr. 145. M. 143. W. 120.

First of three states.

* Proof printed and signed by Whsitler, with his pencilled

की.

A wood near Speke Hall, the seat of Sir F. Leyland.

124. PRICE'S CANDLE FACTORY. (PRICE'S CANDLE WORKS.) Gr. 154 . M. 151 . W. 124.

UNDESCRIBED FIRST STATE, differing from that decribed in the Grolier Club Catalogue in having the stern of the barge at left defined by a line, and in certain lines in the sky, notably a delicate series at the left and a slipped stroke over the bridge. On 18th century paper. OF THE GREATEST RARITY.

* Proof printed and signed by Whistler, with his pencilled

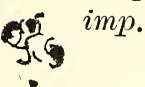

125. PRICE'S CANDLE-FACTORY. (PRICE'S CANDLE WORKS.) Gr. 154. M. $151 . \quad$ W. 124.

UNDESCRIBED STATE, probably between the third state and the fourth, with the sail of the farther barge completely shaded and the sail and barge strongly reflected in the water. In the fourth state the reflections are much reduced by burnishing. OF THE GREATEST RARITY.

* Proof printed and signed by Whistler, with his pencilled C. $i m p$.

This beautiful impression is from the Hutchinson collection and has the blind stamp in the lower left corner. On the back in Whistler's autograph is "Price's Candle Factory. W. 124."

[See Illustration.]

126. BATTERSEA, DAWN. Gr. 155. M. 15\%. W. 125.

First state. Beautiful IMPREssion on 18 th century paper. 
WHISTLER-Continued.

12\%. TEMPLE BAR. Gr. 162. M. 159. W. 133.

THREE IMPRESSIONS (excepting two trial proofs) ARE ALL THAT ARE KNOWN TO EXIST of this rare plate. Mansfield mentions the three as being in the Dutcher (this copy), the Freer and his own collection. Printed on a leaf of 17th Century paper.

128. FREE-TRADE WHARF. Gr. 163. M. 160. W. 134. Third state of five (first with the butterfly). Very fine early impression on thin Japan paper.

129. A SKETCH FROM BILLINGSGATE. Gr. 168. M. 164. W. 130.

Sixth state. On 17th century paper.

130. LITTLE PUTNEY. Gr. 179. M. 176. W. 146.

From the limited edition of Wedmore's "Four Masters of Etching." On Japan paper.

131. THE LITTLE LAGOON. Gr. 186. M. 183. W. 152. Second state. SUPERB IMPRESSION on 18th century paper. One of the "Venice Set."

* The first Venice Set, consisting of twelve plates, were issued in 1880 . Only a very limited number of each were issued, and most of the plates were printed by Whistler personally. Ten of the twelve will be found in this and the following numbers.

132. THE PALACES. Gr. 187. M. 184. W. 153.

A beautiful early impression before the removal of the butterfly. On 18th century paper. Proof printed and signed by Whistler with his pencilled gris imp.

One of the " Venice Set."

133. THE DOORWAY. Gr. 188. M. 185. W. 154.

SECOND STATE of seven. Very beautiful impression on soft 17th century paper, printed in brown. Proof printed and signed by Whistler, with his pencilled gris imp.

* Evidently a trial proof printed by Whistler, before its issue as one of the set, as the margins are not cut close to the 


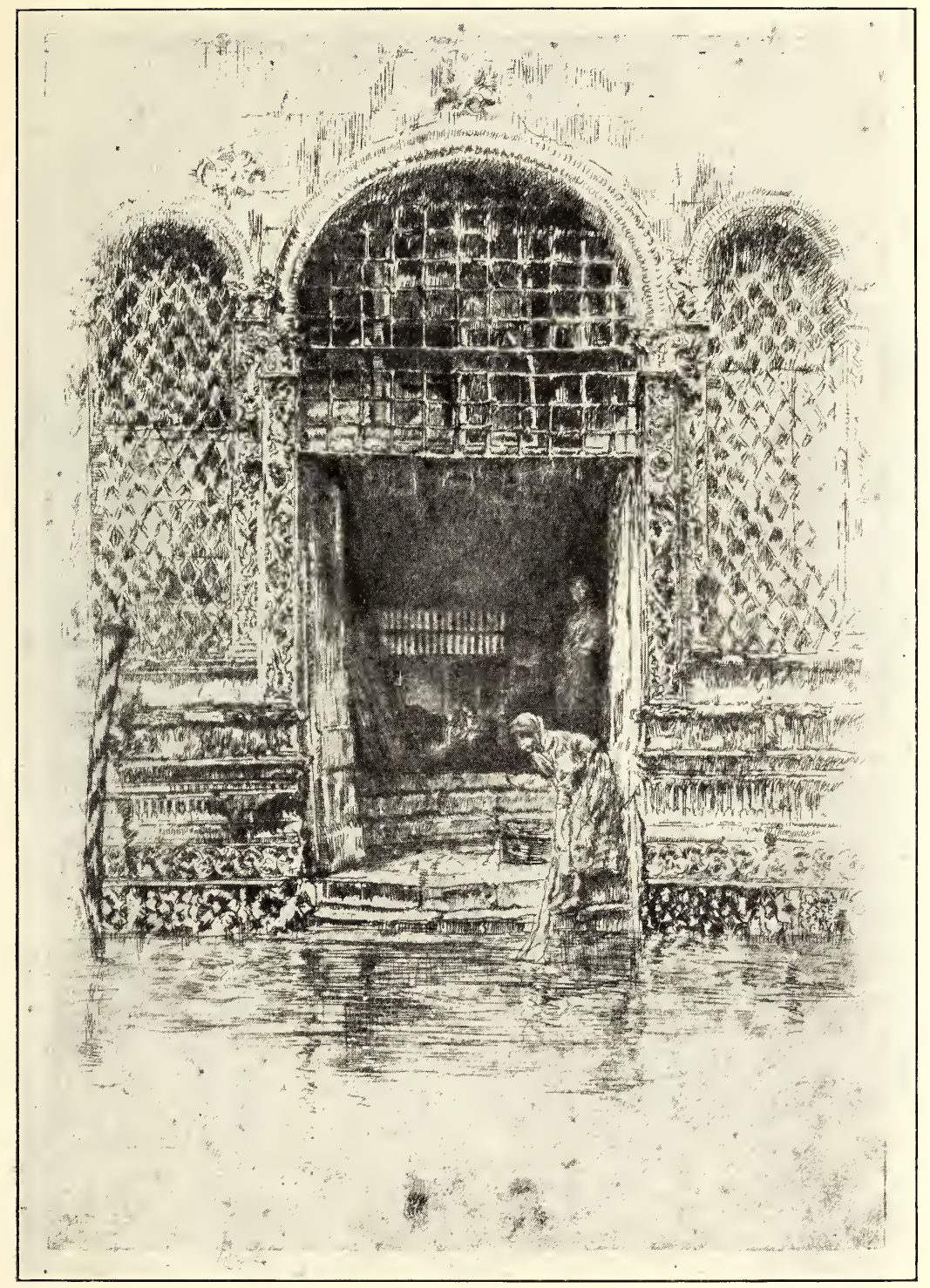

No. 133. The Doorway, by Whistler. 

WHISTLER-Continued.

plate-mark, but are left broad. In a later state one of the

"Venice Set."

The French critics were the first to appreciate the work of Whistler, and it was one of them who characterized this plate as the most brilliant of the Master's jewels. It was while looking at this Venice sec that Sir F. Seymour Haden was asked what he would do if forced to choose between his Rembrandts and his Whistlers, his reply was that the Rembrandts would go first.

[See Illustration.]

134. THE PIAZZETA. Gr. 189. M. 186. W. 155.

Very fine impression of the completed plate on 18th century paper. Proof printed and signed by Whistler, with his pencilled

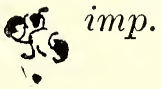

One of the "Venice Set."

135. TRAgheTTO. No. 2. Gr. 191. M. 188. W. 156.

Third state of six (or seven). Very beautiful impression on Japan paper.

One of the "Venice set."

* The impressions on Japan paper are usually early trial proofs, the later issues being on old Dutch paper.

136. THE RIVA. No. $1 . \quad$ Gr. 192. M. 189 . W. $15 \%$.

Third state. Very fine early impression on Japan paper showing the lines in the sky. Proof printed and signed by Whistler, with his pencilled tris $i m p$.

* Possibly an early trial proof, having broad margins and being on Japan paper. One of the "Venice Set."

13\%. THE TWO DOORWAYS. Gr. 193. M. 190. W. 158.

Third state of seven. Superb early impression on Japan paper, with margins. No doubt a trial proof.

Printed and sign by Whistler, with his pencilled aris imp.

* ONe of the RAREST OF WhistLer's ETCHINGS to obtain in a good impression. From the "Venice Set." 
WHISTLER--Continued.

138. THE BEGGARS. Gr. 194. M. 191. W. 159.

Sixth of nine states. Superb impression in brown ink on 18th century paper. Proof printed and signed by Whistler with his pencilled

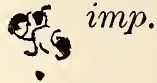

* A French critic has characterized this as one of the most perfect etchings existing in the world. Joseph Pennell writes that " there are no such perfect plates in the world as "The Beggars,' 'The Traghetto,' 'Riva, No. 1 and 2,' and 'The Bridge.'" One of the "Venice Set."

139. THE MAST. Gr. 195. M. 192. W. 160.

Fifth of six states. Superb impression on Japan paper, with margins, no doubt a trial proof. Printed and signed by Whistler, with his pencilled $i m p$.

* One of the " Venice Set."

140. DOORWAY AND VINE. Gr. 196. M. 193. W. 161. Seventh of nine states. Very fine impression on 18th century paper. Proof printed and signed by Whistler, with his pencilled imp.

* In its later state one of the "Twenty-six Etchings" issued in 1886 , of which only 30 were printed.

141. SAN BIAGIO. Gr. 19\%. W. 163. M. 194.

Third state of one of Whistler's most important plates. With collector's stamp "J. C." (J. C. Cox ?)

In Whistler's handwriting on the back " $3 r d$. state."

* In a later state one of the "Twenty-six Etchings."

142. IONG LAGOON. Gr. 203. M. 200. W. 169.

First state, before the butterfly. Very fine impression on 18th century paper. Proof printed and signed by Whistler, with his pencilled Cimp.

* In a later state one of the "Twenty-six Etchings." 
WHISTLER-Continued.

143. UPRIGHT VENICE. Gr. 205. M. 202. W. 172.

Second state of four, before the shading on the back of the man in the front group, and before the lengthening of the reflection of the canopy of the gondola. On 18th century paper. Proof printed and signed by Whistler, with his pencilled imp.; also the title with his auto. graph, $T$ on the back.

* In a later state one of the "Twenty-six Etchings." An unusually fine impression.

\section{THE BALCONY. Gr. $20 \%$ M. 204. W. $17 \%$.}

Fifth of eleven states. Superb impression on 18th century paper. Proof printed and signed by Whistler, with his pencilled $i m p$.

* One of the masterpieces of the series. In a much later state. One of the "Twenty-six Etchings."

145. THE FISHING BOAT. Gr. 208. M. 205. W. 17.8

Fourth state of five. Very fine impression on thin 18th century paper. Proof printed and signed by Whistler, with his pencilled,
One of the "Twenty-six Etchings."

146. LA SALUTE, DAWN. Gr. 215. M. 212. W. 185.

Fourth state. Very fine impression on thin 18th century paper. Proof printed and signed by Whistler, with his peucilled imp. The plate drawn from his window. One of the "Twenty-six Etchings."

147. SWAN AND IRIS. Gr. 241. M. 288. Not in Wedmore's catalogue.

Second state. Very early impression before the fine lines in the sky were worn.

148. THE LITTLE HAT. Gr. 335. M. 331. Not in Wedmore's catalogue.

Only state. Proof printed and signed by Whistler, with his pencilled imp. 
WHISTLER-Continued.

149. THE LITTLE NUDE MODEL READING. Way, 29.

Lithograph on eighteenth century paper.

Very fine impression and rare.

150. WEDMORE'S CATALOGUE.

Whistler's Etchings: a Study and a Catalogue. By Frederick Wedmore. Second edition, revised and enlarged. Crown 8vo, cloth, uncut. London: Colnaghi, 1899.

* Only 135 copies issued, this being No. 64 .

\section{THE DEFACED PLATES.}

A volume containing fifty-seven impressions from the defaced plates, in the original boards and cloth back covers as issued. In perfect condition, some of the impressions being from the plates after the lines of defacement had been burnished down. MANY VERY RARE PLATES ARE INCLUDED. 4to.

* The impression of the plate "Whistler with the White Lock" bear no marks of cancellation.

\section{ANDERS ZORN.}

152. THE WALTZ. D. 54.

Third or finished state. On heavy Van Gelder paper. Proof signed by Zorn.

Forty proofs alone taken and plate destroyed.

* This and "An Interior of an Omnibus" are two of Zorn's most characteristic and most praised plates. Both were exhibited at the "Exposition des Peintres-Gravures francais" in 1893 , where they created much attention, the etcher then being scarcely known.

A French critic in writing of Zorn stated " his method is extremely curious and individual, without apparent method, confused at a close examination, but seen at a proper distance from the eye, becomes clear and precise in a manner that is astonishing, and if dwelt on for a short time a thousand details show themseives that on a superficial examination are not apparent. ALL OF HIS PLATES ARE VERY RARE. 



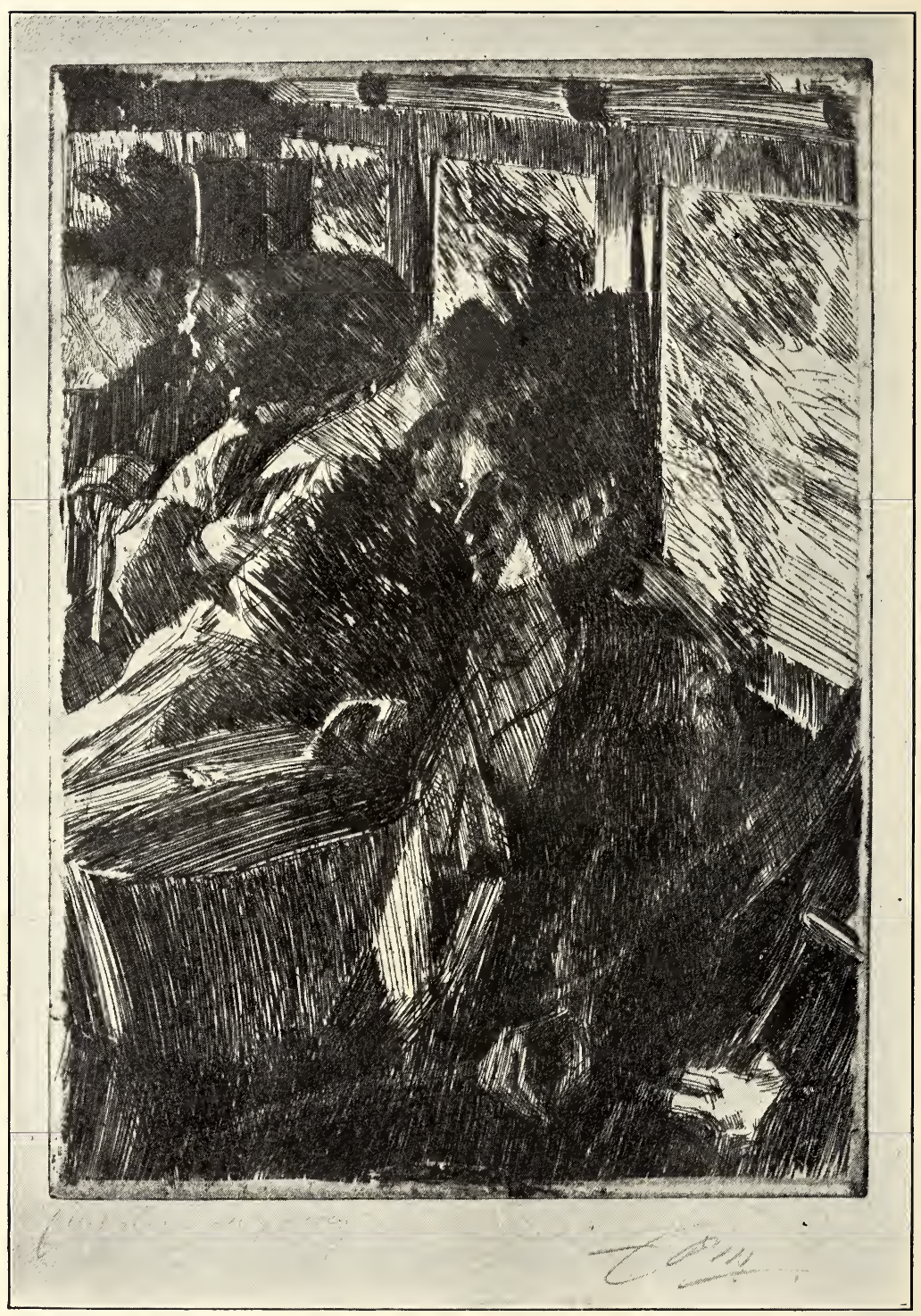

No. 154. INTERIOR OF AN OMNibus, BY ANDERS ZORN. 
ANDERS ZORN-Continued.

153. THE CIGARETTE GIRL (LA DAME Â LA CIGARETTE). First plate. D. 61.

First and only state. ONE OF ONLY THREE PROOFS TAKEN BEFORE THE DESTRUCTION OF THE PLATE. On heavy Van Gelder paper.

Signed by Zorn and with his pencilled note" 1 plate. 3 proofs.

* Delteil mentions the three copies as belonging to Mr. Dutcher, C. Deering and C. Bermond.

154. INTERIOR OF AN OMNIBUS. D. 71.

First state. THE ONLY KNOWN COPY, described in Delteil's catalogue as belonging to $\mathrm{Mr}$. Dutcher. On heavy Van Gelder paper.

Signed by Zorn and with his autograph note "Ier. état. Unique."

[See Illustration.]

155. INTERIOR OF AN OMNIBUS. D. 71 .

Third state. On heavy Van Gelder paper.

Proof signed by Zorn.

* The plate was destroyed after 75 impressions had been taken.

156. AN OLD BALLAD (VIEILLE BALLADE). Second plate. D. 126.

First and only state. On heavy Van Gelder paper. Proof signed by Zorn.

* Thirty proofs taken and plate destroyed.

- 15\%. THE SWEDISH MADONNA (IAA MËRE, OR, LA MADONE). D. 150 .

Second state of three. On Japan paper.

Proof signed by Zorn.

158. AT THE PIANO (AU PIANO). D. 159.

Second state. On Dutch paper.

Proof signed by Zorn.

Sixty or seventy proofs taken and plate destroyed.

* A portrait of Miss Anna Burnett.

159. A NEW BALLAD (NOUVELLE CHANSON). D. 169. First and only state. On Van Gelder paper.

Proof signed by Zorn. 
ANDERS ZORN-Continued.

160. MLLE. EMMA RASSMUSSEN. D. 182.

First and only state. On heavy Van Gelder paper. Proof signed by Zorn.

161. MRS. KIP. D. 183.

First and only state. On heavy Van Gelder paper.

Proof signed by Zorn.

Only 35 proofs taken and plate destroyed.

* This copy is mentioned by Delteil.

[See Illustration.]

162. THE BRIDESMAID (DEMOISELLE D'HONNEUR).

D. 191.

First and only state. On Dutch paper.

Proof signed by Zorn. 


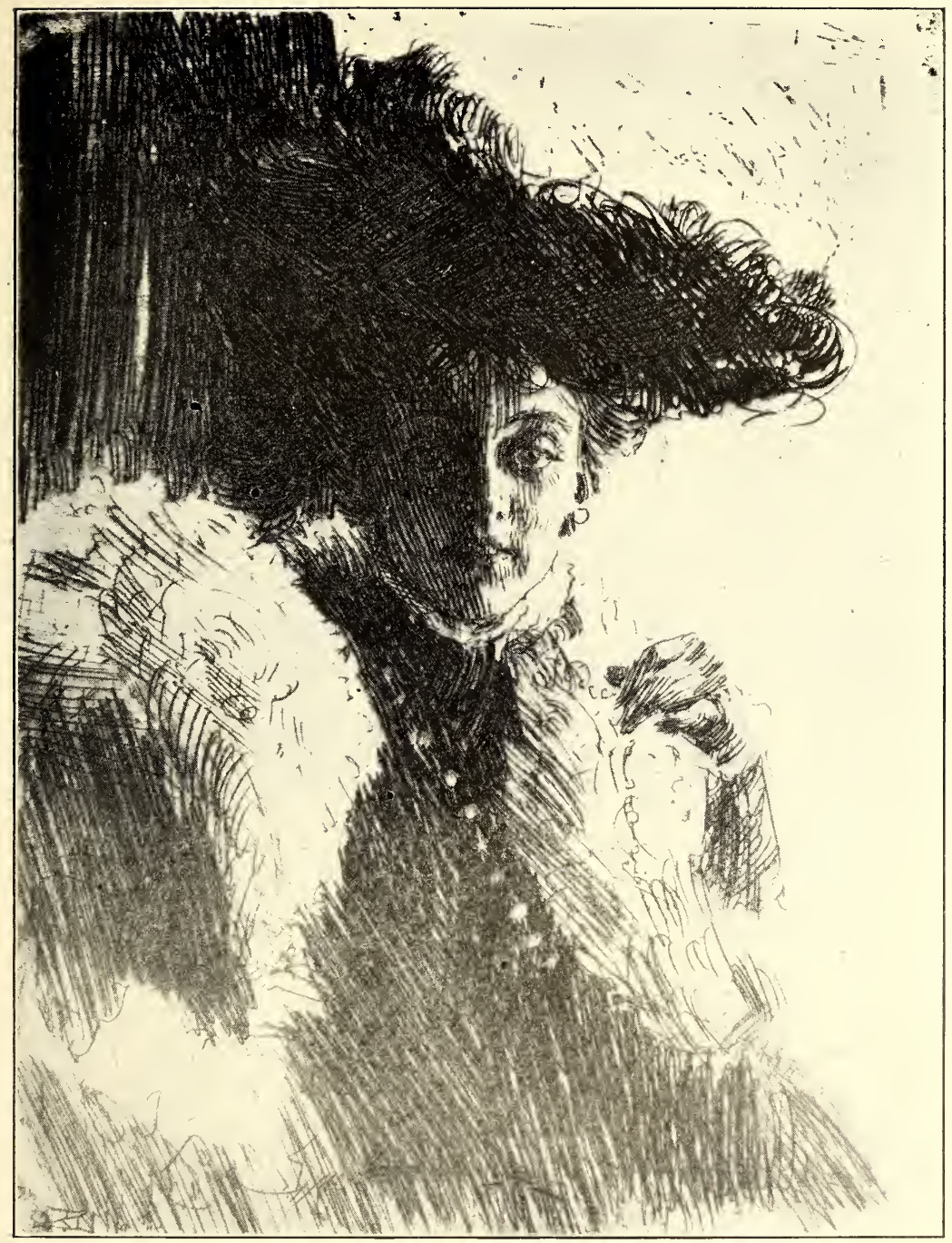

No. 161. Mrs. Kip, by ANders Zorn. 





\section{Sales of Important Literary and Art Collections only}

\section{The Anderson Aurtion Company}

12 East 46th Street, New York.

The Season of 1910-11 opened on October 10. Since that time Fifty-four Sales' Sessions have been held of Libraries and Collections of Prints, Stamps, Porcelains and Objects of Art. The season promises to be one of unequalled interest to buyers and collectors, during which the great Private Library of the late Robert Hoe is to be sold (see announcement below).

\section{Among other Collections in Preparalion are}

Books, Letters and Manuscripts of S. L. Clemens (Mark Twain).

Part II of the Americana of Wilberforce Eames, of the Lenox Library.

An Important Collection of Autographs, including Burns, Hawthorne, etc.

A Private Collection of Books on Angling.

Antique Furniture of Paul Warren, Richfield Springs, N. Y.

Paintings and Studio Property of the late Francis Lathrop.

The Important Whistler Collection of J. S. Dutcher, of Ellenville, N. Y.

Library, MSS. and Prints of the late Judge Jacob Klein, of St. Louis, Mo.

Several Important Collections of Paintings and Prints (details later).

THE ROBERT HOE LIBRARY-It is with peculiar interest that we announce the sale of this great library, the largest and most important in the Annals of Book Auctions. The first sale will be held in the new Galleries of the Company in February. Full announcement of the sale will be made later.

ART COLLECTIONS-In February we shall remove to the magnificent new fireproof building recently acquired by us at Madison Avenue and 4oth Street. Special attention will be given to the sale of meritorious Art Collections for the exhibition and sale of which our new Galleries will afford the highest facilities. Expert information on request.

Executors and Administrators of Eslates having Libraries or Art Collections to sell, Librarians, Publishers and Booksellers are invited to correspond with us. Catalogues mailed on request. 


\section{BUSINESS IN MADISON AVENUE}

THE business transformation of Madison Avenue just north of the restricted Murraj

Hill zone at Thirty-eighth Street has made great strides this year, and it seems tolerably safe to predict that within a short time the four blocks from the north side of Thirty-eighth Street to Forr y-second Street will be devoted to commercial uses.

The leasing of the magnificent home belonging to Mrs. Clarence M. Hyde at the northwest corner of the avenue and Fortieth Street to THE ANDERson Auction ComPANY for a term of twenty-one years at an aggregate rental of $\$ 500,000$ is perhaps the greatest blow to the private-house stability of this section of Madison Avenue that has thus far occurred. To be sure, the changes about to be made in the Hyde House are of a high-class character, not such as in themselves would mar the residential excellence of the avenue. It is, however, an invasion of business, and several other houses in the vicinity are being altered for commercial uses and apartments.

The officers of The Anderson Auction Company, in selecting this corner for their book and art auction business, were influenced by the fact that their new home is practically in the uptown art centre. Extensive changes are now being made, but the house will not be opened for the auction business until about January I. The present quarters at 12 East Forty-sixth Street will be retained until that time. The company moved to the latter house from Twenty-ninth Street two years ago, and in that time has outgrown its first uptown home.

Adjoining the Hyde residence on the Fortieth Street side was a vacant lot, upon which the lessees are building an extension. Over 40,000 square feet will be available for exhibition and sales purposes. A large room for the sale of paintings and other works of art will be on the top floor and the book-auction rooms will be on a lower story. The Hyde house with the lot adjoining occupies a corner 5 I.9 feet on Madison Avenue and 125 feet on 4 oth St. (with a rear extension of the 40 th St. lot $25 \times 40$ feet).

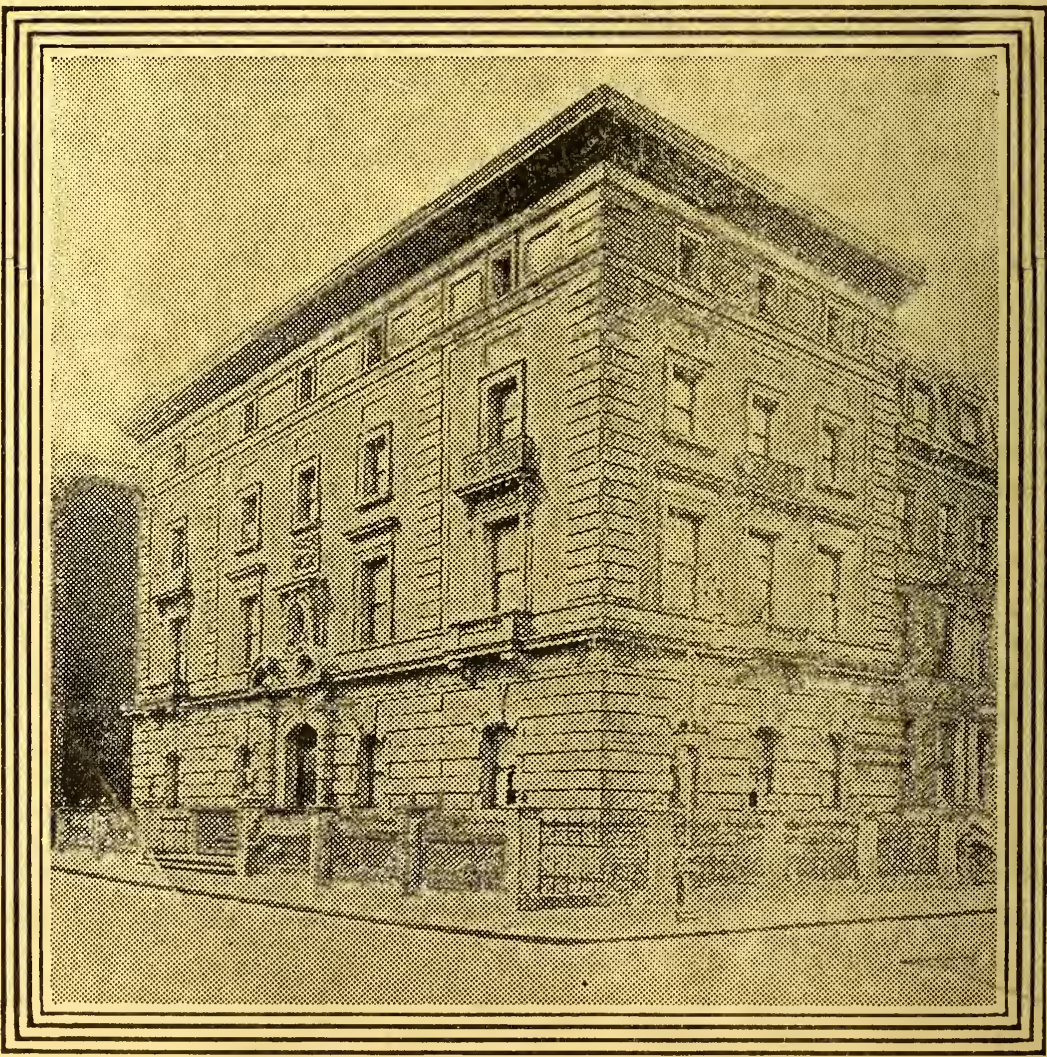

Hyde Residence on 4oth Street Corner Leased for the New Home of The Anderson Auction Company 